\title{
Indoor Dust-Based Pollution Status and Risk Assessment for a Rural Town, Ebedei in Nigeria Hosting Gas Flare Facility
}

\author{
N. Boisa*, B. U. Odagwe \\ Department of Chemistry, Rivers State University, Port Harcourt, Nigeria \\ Email: `boisa.ndokiari@ust.edu.ng
}

How to cite this paper: Boisa, N. and Odagwe, B.U. (2019) Indoor Dust-Based Pollution Status and Risk Assessment for a Rural Town, Ebedei in Nigeria Hosting Gas Flare Facility. Journal of Environmental Protection, 10, 208-220. https://doi.org/10.4236/jep.2019.102012

Received: December 6, 2018

Accepted: January 30, 2019

Published: February 2, 2019

Copyright $\odot 2019$ by author(s) and Scientific Research Publishing Inc. This work is licensed under the Creative Commons Attribution International License (CC BY 4.0).

http://creativecommons.org/licenses/by/4.0/ (c) (i) Open Access

\begin{abstract}
Recently, there has been series of petitions and protestations from petroleum production gas flare facility host communities in Nigeria about the degradation of their environment. This study was designed to conduct indoor dust related human health risk assessment for $\mathrm{Cd}, \mathrm{Pb}, \mathrm{Mn}$ and Ni. Deposited indoor dust samples were collected from sixteen (16) residential buildings distributed across the four quarters of Ebedei waterside town in Nigeria, within the vicinity of a petroleum production gas flare facility. The samples were digested and analysed for $\mathrm{Cd}, \mathrm{Pb}, \mathrm{Mn}$ and $\mathrm{Ni}$ concentrations using inductively coupled plasma mass spectrometry (ICP-MS). Contamination/pollution in$\operatorname{dex}(\mathrm{C} / \mathrm{PI})$ and human health risk assessments were conducted. The concentration ranges of $1.2-14.9 \mathrm{mg} / \mathrm{kg}, 44.0-161.6 \mathrm{mg} / \mathrm{kg}$ and $221.3-752.0$ $\mathrm{mg} / \mathrm{kg}$, and below detection to $29.8 \mathrm{mg} / \mathrm{kg}$ were recorded for $\mathrm{Cd}, \mathrm{Pb}, \mathrm{Mn}$ and $\mathrm{Ni}$, respectively. C/PI analyses for metals in the indoor dusts investigated suggested $\mathrm{Cd}$ levels to be polluted and $\mathrm{Pb}$ levels to be slightly polluted, while $\mathrm{Mn}$ and Ni levels indicated contamination. Risk assessment studies indicated that children may be more at risk for all the three exposure pathways. Exposure through the ingestion pathway indicated the highest risk for both the adult and children population.
\end{abstract}

\section{Keywords}

Gas Flare Facility, Ebedei, Risk Assessment, Heavy Metals

\section{Introduction}

Indoor dust is a conglomerate of particulate matter from several sources in the indoor environments [1] [2]. Most depositions of metals associated with com- 
bustion occur in the particulate form [3]. Indoor dust is a source of deposition of heavy metals in potentially harmful quantities to human beings [4]. Concentrations of potentially toxic metals like $\mathrm{Pb}$ and $\mathrm{Mn}$ in settled house dust correlated significantly with concentrations in re-suspended health relevant fractions [5]. We are most likely to contact indoor dust because a significant proportion of time is spent in the indoors [6]. So, the indoor dust is an important exposure pathway to heavy metals for humans [7].

In the indoor environment, heavy metals are released from consumer products, furniture and building materials and through occupants' activities such as smoking and incense burning [8]. The major migration pathways for inorganic contaminants, such as heavy metals, from the exterior environment to the interior environment are the infiltration of contaminated outdoor air and the track-in of soil adhering to foot and footwear [9].

A good number of researchers have reported in various studies the levels of heavy metals in indoor dust from residential buildings [7] [10] [11] [12], especially in cities and urban centres. In Nigeria, however, only a few studies have been carried out to examine the concentrations of heavy metals in the indoor dust of environment [13]. Ebedei Waterside is a rural community in Delta State of Nigeria and the major economic activity taking place in the community is farming. However, the community is a host to an oil exploration facility which flares gas at a rate that is being feared to be introducing harmful substances at a high level into the community environment.

Metals in the indoor dust can accumulate in the human body through inhalation of re-suspended dust particles, ingestion of dust particles as a result of hand-to-mouth and object-to-mouth actions, and/or through dermal contact absorption of dust particles [14]. An increasing global concern is being given to the contamination of the indoor environment by heavy metals in order to investigate their impact on human health and to minimize health risks [15] [16] [17].

Children have been reported in various studies such as that of to have great susceptibility to the menace of the pollution of the indoor environment by heavy metals [13] [18]. Due to their frequent playing on the ground and mouthing of hand and other objects in the process, children take in more contaminated indoor dust each day as compared to the incidental ingestion of dust particles by adult [19]. Children are very vulnerable to heavy metal poisoning as their organs (the brain for example) are in a period of active growth and differentiation, making them have low tolerance to toxins [20].

The effects of metal contaminated indoor dust on human health is presently well publicized, but there is currently a paucity data on the emissions constituents from petroleum-based gas flare and their possible impact on the environment due to restricted access to the facility [21]. Risk assessment estimates the severity of harm to human and other receptors that may result from exposure to chemicals present in the environment [22]. Human induced enrichment of toxic metals in dust to concentrations beyond "safe" levels is likely to cause harm to human at site of gas flare. Nigeria is currently the second ranking country in vo- 
lume of gas flared in the world [23]. This study was therefore designed to determine the concentrations of selected heavy metal in indoor dust within the vicinity of a gas flare facility and estimate possible human health risk for a gas flare rural community.

\section{Materials and Method}

\subsection{Description of the Study Area}

The study was done in Ebedei Waterside, one of two geographically separated regions of Ebedei community; the other being called Ebedei-Uno. Ebedei Waterside lies between $5^{\circ} 52^{\prime} \mathrm{N}$ and $6^{\circ} 11^{\prime} \mathrm{E}$, and $5^{\circ} 54^{\prime} \mathrm{N}$ and $6^{\circ} 13^{\prime} \mathrm{E}$ along the coast of River Ethiope and it is just around $3 \mathrm{~km}$ away from Obiaruku, the Local Government Headquarters. It is divided into four smaller quarters; Obi-Iloh (Umuosele), Obi-Ogene (Umueziogoli), Adonishaka (Ogbe-Uzu) and Ukwuole, with each quarter having four streets. Farming is the common economic activity of the people living in the four quarters. Ebedei Waterside also play host to Platform Petroleum Company-an oil exploration company.

\subsection{Sampling}

Indoor dust samples were collected from sixteen (16) residential buildings in Ebedei Waterside (Figure 1). Four samples from the four streets of each quarter. The collection was done with the aid of a plastic brush and a plastic pan. For every portion of a composite sample, a clean set of plastic brush and plastic pan was used to scoop deposited indoor dust particles from the surfaces of various objects within the residential apartments into a fresh and clean plastic tube. Of the varying surfaces of indoor object from which the deposited dusts were collected, the surfaces of ceiling fans were the most prominent. After the samples from the sixteen sites have been collected into separate plastic tubes, they were all packed together and transferred to the laboratory for subsequent preparations and analysis.

\subsection{Sample Digestion and Instrumental Analysis}

The collected samples were kept in the sealed plastic tubes in the laboratory until preparation for analysis. In preparation for analysis, a $0.5 \mathrm{~g}$ portion of each of the collected samples were measured in duplicates and were all digested with 20 $\mathrm{ml}$ aqua regia (mixture of $\mathrm{HCl}$ and $\mathrm{HNO}_{3}$ in the ratio of 3:1) by heating them in a solution of the acid mixture for 2 hours. The mixtures were then filtered and the filtrates were diluted to $50 \mathrm{ml}$ with deionized water. The contents of $\mathrm{Cd}, \mathrm{Pb}$, $\mathrm{Mn}$ and $\mathrm{Ni}$ were then determined in all the samples using inductively coupled plasma-mass spectrometry (ICP-MS).

\subsection{Contamination/Pollution Index (C/PI)}

A comparison between the concentrations of heavy metals in the sampled sites and their reference levels was done to establish a contamination/pollution index 


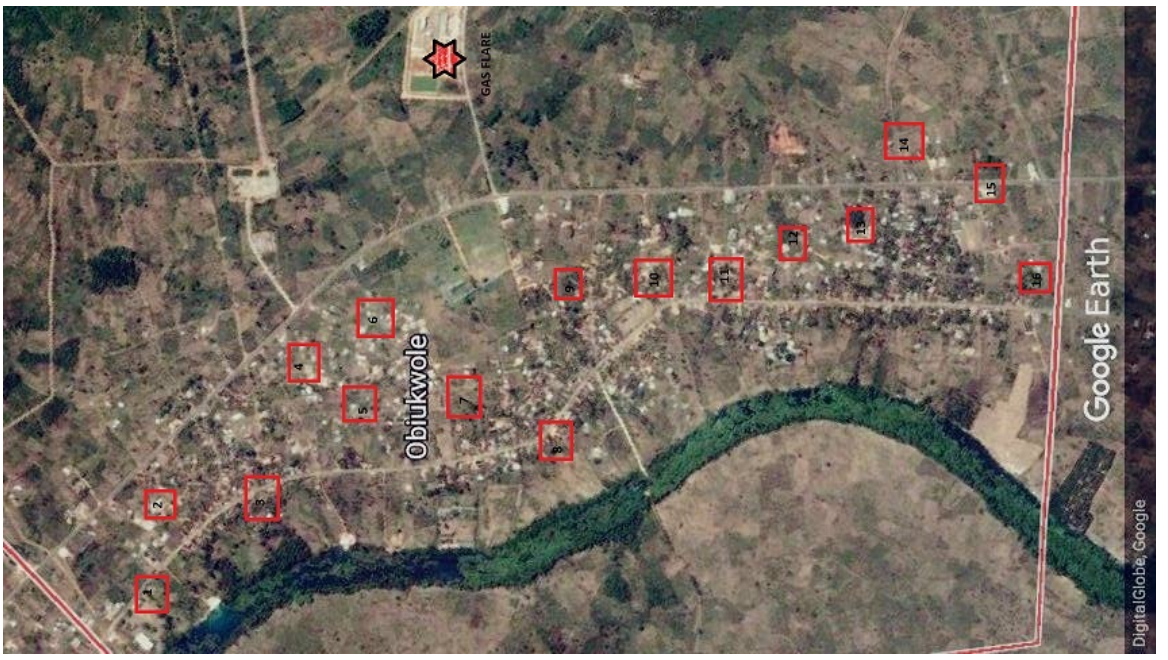

Figure 1. Google map showing the 12 sample locations.

for each of the studied elements in the studied area. This provides adequate information about the significance of the measured concentrations of metals in the indoor dust samples and how the values obtained are related to the maximum allowable limits for the metals [24]. It was derived by employing the contamination/pollution index as previously applied [25].

$$
C / P I=\frac{\text { concentration of metal in dust }}{\text { reference value }}
$$

No allowable maximum levels of heavy metals have been established for dust samples (indoor or outdoor) by the time of doing this study, hence; the reference values used in this case is the Department of Petroleum Resources of Nigeria maximum allowable levels of metals in soil [26] as stated listed in Table 1.

The categorization of degree of contamination/pollution based on this index is as follows: $<0.10=$ very slight contamination; $0.10-0.25=$ slight contamination; $0.26-0.50=$ moderate contamination; $0.51-0.75=$ severe contamination; 0.76 $1.00=$ very severe contamination; $1.10-2.00=$ slight pollution; $2.10-4.00=$ moderate pollution; $4.10-8.00=$ severe pollution; $8.10-16.00=$ very severe pollution; $>16.00=$ excessive pollution.

\subsection{Human Exposures and Risk Assessment}

Humans are exposed to these contaminants through three major pathways- inhalation, ingestion and dermal absorption. The intake doses from the respective exposure pathways by the children and adult populations were estimated using Equations (2), (3) and (4) adapted from US EPA [27]. The individual terms and their values inputted into the risk assessment equations are provided in Table 2.

$$
\begin{aligned}
& D_{\text {inh }}(\mathrm{mg} / \mathrm{kg} / \text { day })=C(\mathrm{mg} / \mathrm{kg}) \times \frac{i n h R \times E F \times E D}{P E F \times A B W \times A T} \\
& D_{\text {ing }}(\mathrm{mg} / \mathrm{kg} / \text { day })=C(\mathrm{mg} / \mathrm{kg}) \times \frac{i n g R \times E F \times E D}{A B W \times A T} \times 10^{-6}
\end{aligned}
$$


Table 1. Reference values of heavy metals (mg/kg).

\begin{tabular}{cc}
\hline Metal & Reference value \\
\hline $\mathrm{Cd}$ & 0.8 \\
$\mathrm{~Pb}$ & 85 \\
$\mathrm{Mn}$ & $850^{*}$ \\
$\mathrm{Ni}$ & 35 \\
\hline
\end{tabular}

${ }^{*}$ Derived from the crustal abundance value. Adapted from [26].

Table 2. Description of parameters used in the health risk assessment.

\begin{tabular}{|c|c|c|c|c|}
\hline \multirow{2}{*}{ Parameters } & \multirow{2}{*}{ Definition } & \multicolumn{2}{|c|}{ Values } & \multirow{2}{*}{ References } \\
\hline & & Child & Adult & \\
\hline $\mathrm{C}$ & Metals concentration in dust & & & \\
\hline inhR & Inhalation rate & $7.6 \mathrm{~m}^{3} /$ day & $20 \mathrm{~m}^{3} /$ day & [29] \\
\hline ingR & Ingestion rate & $200 \mathrm{mg} /$ day & $100 \mathrm{mg} /$ day & [30] \\
\hline $\mathrm{EF}$ & Exposure frequency & \multicolumn{2}{|c|}{180 days/year } & [29] \\
\hline $\mathrm{ED}$ & Exposure duration & 6 years & 24 years & \\
\hline AT & Averaging time & \multicolumn{2}{|c|}{$\begin{array}{c}\text { ED } \times 365 \text { days } \\
(\text { for non-carcinogenic), } 25,550 \\
\text { days }(\text { for carcinogenic) }\end{array}$} & \\
\hline PEF & Particle emission factor & \multicolumn{2}{|c|}{$1.36 \times 10^{9} \mathrm{~m}^{3} / \mathrm{kg}$} & [31] \\
\hline SA & Exposed skin area & $2800 \mathrm{~cm}^{2}$ & $5700 \mathrm{~cm}^{2}$ & \\
\hline SAF & Skin adherence factor & $0.2 \mathrm{mg} / \mathrm{cm}^{2} /$ day & $0.07 \mathrm{mg} / \mathrm{cm}^{2} /$ day & \\
\hline DAF & Dermal absorption factor & \multicolumn{2}{|c|}{0.001} & [10] \\
\hline ABW & Average body weight & $15 \mathrm{~kg}$ & $70 \mathrm{~kg}$ & [32] \\
\hline $\mathrm{CR}$ & $\begin{array}{c}\text { Contact rate } \\
(\text { inhR or ingR or SA } \times \text { SAF } \times \text { DAF })\end{array}$ & & & [27] \\
\hline
\end{tabular}

The non-carcinogenic and carcinogenic risks as a result of exposures to the metals in the dust samples were considered in this study. The non-carcinogenic risks were estimated using a factor known as the Hazard Quotient (HQ) - the ratio of the intake doses from each of the pathways to the respective reference intake doses $(R f D)$ for each metal across each pathway, as shown in Equation (5). The cumulative non-carcinogenic hazard risk from all the exposure pathways was rated as the Hazard Index (HI) for children and adults as calculated using equation provided by US EPA [27].

$$
\begin{gathered}
\text { Hazard Quotient }(H Q)=\frac{D}{R f D} \\
\text { Hazard Index }(H I)=\sum H Q=H Q_{i n h}+H Q_{\text {ing }}+H Q_{\text {dermal }}
\end{gathered}
$$

In the assessment of the carcinogenic risk, the lifetime average daily dose 
$(L A D D)$, a weighted average of the intake doses of a contaminant over a lifetime [28] was calculated for $C d$ and $\mathrm{Ni}-$ the two carcinogens considered in this study-through the inhalation route of exposure, as shown in Equation (7) below. To quantitatively estimate the carcinogenic risk $(C R)$, the $L A D D$ was multiplied by the inhalation slope factor $(S F)$.

$$
L A D D(\mathrm{mg} / \mathrm{kg} / \text { day })=\frac{C(\mathrm{mg} / \mathrm{kg})}{A T} \times\left[\frac{C R_{\text {child }} \times E D_{\text {child }}}{B W_{\text {child }}}+\frac{C R_{\text {adult }} \times E D_{\text {adult }}}{B W_{\text {adult }}}\right]
$$

\section{Results and Discussion}

The concentrations of cadmium, lead, manganese and nickel in four different samples of indoor dust from each of the four quarters of Ebedei and their respective mean values are provided in Table 3. All the metals investigated in study have previously been found in suspended particulate matter of the study location [33]. Excluding Mn the other three metals investigated in this study also indicated enrichment factors above 40.

The mean concentrations of cadmium in the indoor dust of Obi-Iloh, Obi-Ogene, Adonishaka and Ukwuole were $6.2 \mathrm{mg} / \mathrm{kg}, 4.8 \mathrm{mg} / \mathrm{kg}, 5.2 \mathrm{mg} / \mathrm{kg}$ and $3.0 \mathrm{mg} / \mathrm{kg}$ respectively (Table 3 ). All means recorded for the four quarters were above the $0.8 \mathrm{mg} / \mathrm{kg}$ permissible value set by the Nigerian Department of Petroleum Resources for soil matrix [26]. The range of means of the concentrations observed for Cd in four quarter of the study area $3.0-6.2 \mathrm{mg} / \mathrm{kg}, 4.8 \mathrm{mg} / \mathrm{kg}$ is above the range of $<0.05 \mathrm{mg} / \mathrm{kg}$ previously reported by Asia et al. (2007) [34] for surface soil at flare site in Nigeria. The range of Cd, $1.2 \mathrm{mg} / \mathrm{kg}$ and $14.9 \mathrm{mg} / \mathrm{kg}$ obtained in this study consistent with the range of $0.2 \mathrm{mg} / \mathrm{kg}$ to $20 \mathrm{mg} / \mathrm{kg}$ reported for Cd in the city of Instabul, Turkey [10].

The mean concentrations of lead in the samples from Obi-Iloh, Obi-Ogene, Adonishaka and Ukwuole were $98.9 \mathrm{mg} / \mathrm{kg}, 132.4 \mathrm{mg} / \mathrm{kg}, 79.0 \mathrm{mg} / \mathrm{kg}$ and 79.5 $\mathrm{mg} / \mathrm{kg}$ respectively (Table 3 ). Mean values recorded for Obi-Iloh and Obi-Ogene were both above the $85.0 \mathrm{mg} / \mathrm{kg}$ reference value set by the Nigerian Department of Petroleum Resources for soil matrix [26], while those recorded for Adonisha$\mathrm{ka}$ and Ukwuole were below the set reference value. The mean concentrations of the four quarters, $98.9 \mathrm{mg} / \mathrm{kg}, 132.4 \mathrm{mg} / \mathrm{kg}, 79.0 \mathrm{mg} / \mathrm{kg}$ and $79.5 \mathrm{mg} / \mathrm{kg}$ are consistent with the concentration, $99.4 \mathrm{mg} / \mathrm{kg}$ reported previously [33] for surface soil at a gas flare facility in Niger delta, Nigeria. Also the range of means (79.0 $132.4 \mathrm{mg} / \mathrm{kg}$ ) recorded in this study is consistent with $60.1-388 \mathrm{mg} / \mathrm{kg}$ [34] and $3-230 \mathrm{mg} / \mathrm{kg}$ [10] reported for indoor dust in other parts of the world.

The mean concentrations of manganese in the indoor dusts of Obi-Iloh, Obi-Ogene, Adonishaka and Ukwuole were $386.9 \mathrm{mg} / \mathrm{kg}, 604.9 \mathrm{mg} / \mathrm{kg}, 406.7$ $\mathrm{mg} / \mathrm{kg}$ and $282.7 \mathrm{mg} / \mathrm{kg}$ respectively (Table 3 ). All the recorded mean values for the four quarters were below the $650.0 \mathrm{mg} / \mathrm{kg}$ reference value set by the Nigerian Department of Petroleum Resources for soil matrix [26].

In the case of nickel, the recorded mean concentrations in Obi-Iloh, Obi-Ogene, Adonishaka and Ukwuole were $23.0 \mathrm{mg} / \mathrm{kg}, 19.9 \mathrm{mg} / \mathrm{kg}, 17.0 \mathrm{mg} / \mathrm{kg}$ 
Table 3. Concentrations of cadmium, lead, manganese and nickel in the four quarters of Ebedei.

\begin{tabular}{|c|c|c|c|c|c|}
\hline Quarter & Sample code & Cadmium & Lead & Manganese & Nickel \\
\hline & \multicolumn{5}{|c|}{$\mathrm{mg} / \mathrm{kg}$} \\
\hline \multirow[t]{5}{*}{ Obi-Iloh } & 1 & 14.9 & 153.8 & 483.0 & 24.5 \\
\hline & 2 & 4.3 & 88.0 & 333.9 & 17.0 \\
\hline & 3 & 2.8 & 44.0 & 283.0 & 26.6 \\
\hline & 4 & 2.8 & 109.8 & 447.5 & 24.5 \\
\hline & Mean & 6.2 & 98.9 & 386.9 & 23.0 \\
\hline \multirow[t]{5}{*}{ Obi-Ogene } & 5 & 3.3 & 109.6 & 544.0 & 22.3 \\
\hline & 6 & 2.3 & 107.6 & 501.3 & 27.6 \\
\hline & 7 & 6.2 & 150.8 & 622.4 & 29.8 \\
\hline & 8 & 7.2 & 161.6 & 752.0 & b.d \\
\hline & Mean & 4.8 & 132.4 & 604.9 & 19.9 \\
\hline \multirow[t]{5}{*}{ Adonishaka } & 9 & 5.6 & 140.0 & 617.2 & 1.1 \\
\hline & 10 & 6.2 & 53.8 & 361.3 & 23.4 \\
\hline & 11 & 4.0 & 55.5 & 271.5 & 24.6 \\
\hline & 12 & 5.0 & 66.6 & 376.9 & 19.1 \\
\hline & Mean & 5.2 & 79.0 & 406.7 & 17.0 \\
\hline \multirow[t]{5}{*}{ Ukwuole } & 13 & 2.8 & 77.7 & 221.3 & 19.2 \\
\hline & 14 & 5.0 & 76.6 & 224.7 & 19.1 \\
\hline & 15 & 2.8 & 66.6 & 356.1 & 22.3 \\
\hline & 16 & 1.2 & 96.9 & 328.7 & 25.6 \\
\hline & Mean & 3.0 & 79.5 & 282.7 & 21.6 \\
\hline \multicolumn{2}{|c|}{ Reference (DPR, 2002) } & 0.8 & 85.0 & 850.0 & 35.0 \\
\hline
\end{tabular}

and $21.6 \mathrm{mg} / \mathrm{kg}$ respectively (Table 3 ). All of which values were below the set reference value of $35.0 \mathrm{mg} / \mathrm{kg}$ for nickel in soil matrix by the Nigerian Department of Petroleum Resources [26]. The mean concentrations, $23.0 \mathrm{mg} / \mathrm{kg}, 19.9$ $\mathrm{mg} / \mathrm{kg}, 17.0 \mathrm{mg} / \mathrm{kg}$ and $21.6 \mathrm{mg} / \mathrm{kg}$ are above the concentration, $6.7 \mathrm{mg} / \mathrm{kg}$ reported previously [33] for surface soils around the vicinity of a gas flare facility in Nigeria. The means obtained for the four quarters of Ebedei in this study, 23.0 $\mathrm{mg} / \mathrm{kg}, 19.9 \mathrm{mg} / \mathrm{kg}, 17.0 \mathrm{mg} / \mathrm{kg}$ and $21.6 \mathrm{mg} / \mathrm{kg}$ are consistent with range of concentration mean, $17.1-53.6 \mathrm{mg} / \mathrm{kg}$ obtained for 12 rural cities in China [35].

\section{Contamination/Pollution Index (C/PI)}

The index values presented in Table 4 show that Cd levels in the studied area are within the range of moderate to severe pollution. The $\mathrm{Pb}$ levels range between severe contaminations to slight pollution for the four quarters. Mn concentrations ranged between moderate to severe contaminations in the four quarters 
Table 4. Contamination/pollution index of $\mathrm{Cd}, \mathrm{Pb}, \mathrm{Mn}$ and $\mathrm{Ni}$ for deposited indoor dust.

\begin{tabular}{ccccc}
\hline Quarter & $\mathrm{Cd}$ & $\mathrm{Pb}$ & $\mathrm{Mn}$ & $\mathrm{Ni}$ \\
\hline Obi-Iloh & 7.75 & 1.16 & 0.46 & 0.66 \\
Obi-Ogene & 6.00 & 1.56 & 0.71 & 0.57 \\
Adonishaka & 6.50 & 0.93 & 0.48 & 0.49 \\
Ukwuole & 3.75 & 0.94 & 0.33 & 0.62 \\
\hline
\end{tabular}

$<0.10=$ very slight contamination; $0.10-0.25=$ slight contamination; $0.26-0.50=$ moderate contamination; $0.51-0.75=$ severe contamination; $0.76-1.00=$ very severe contamination; $1.10-2.00=$ slight pollution; $2.10-4.00=$ moderate pollution; $4.10-8.00=$ severe pollution; $8.10-16.00=$ very severe pollution; $>16.00=$ excessive pollution.

studied. Ni concentration levels suggest that the town is contaminated severely.

\section{Health Risk Assessment}

Predicted daily intake doses for the oral pathway is higher than those obtained for the dermal and inhalation exposures for all population types considered (Table 5). Hazard quotient values followed the same sequence; suggesting that humans are more at risk of non-carcinogenic effect when exposed to these heavy metals through the ingestion mode than the other two modes of exposure as greater percentage of the HI values of the studied metals is contributed by the $\mathrm{HQ}_{\text {ing. }}$. This is consistent with several reports elsewhere [28] [34] [36]. Also the daily intake doses predicted for children are above those for adults irrespective of the pathway.

For $\mathrm{Cd}$ in samples the estimated daily intake dose ranges are $(3.2 \mathrm{E}-05$ $\left.8.8 \mathrm{E}-10 \mu \mathrm{g} \cdot \mathrm{kg}_{\mathrm{BW}}^{-1} \cdot \mathrm{d}^{-1}\right)$ and $\left(3.2 \mathrm{E}-06-5.0 \mathrm{E}-10 \mu \mathrm{g} \cdot \mathrm{kg}_{\mathrm{BW}}^{-1} \cdot \mathrm{d}^{-1}\right)$ for children and adults, respectively for all three pathways (Table 5 ). The daily intake doses predicted for both children and adults in Ebedei are below the known reference doses of $1.0 \mathrm{E}-03 \mu \mathrm{g} \cdot \mathrm{kg}_{\mathrm{BW}}^{-1} \cdot \mathrm{d}^{-1}, \quad 1.0 \mathrm{E}-03 \mu \mathrm{g} \cdot \mathrm{kg}_{\mathrm{BW}}^{-1} \cdot \mathrm{d}^{-1}$ and $5.05 \mathrm{E}-05$ $\mu \mathrm{g} \cdot \mathrm{kg}_{\mathrm{BW}}^{-1} \cdot \mathrm{d}^{-1}$ for ingestion, inhalation and dermal, respectively. For $\mathrm{Pb}$ in samples the estimated daily intake dose ranges are $(6.4 \mathrm{E}-04-1.0 \mathrm{E}-08$ $\left.\mu \mathrm{g} \cdot \mathrm{kg}_{\mathrm{BW}}^{-1} \cdot \mathrm{d}^{-1}\right)$ and $\left(6.9 \mathrm{E}-05-1.0 \mathrm{E}-08 \mu \mathrm{g} \cdot \mathrm{kg}_{\mathrm{BW}}^{-1} \cdot \mathrm{d}^{-1}\right)$ for children and adults, respectively for all three pathways (Table 5 ). The daily intake doses predicted for both children and adults in Ebedei are below the known reference doses of $3.5 \mathrm{E}-03 \mu \mathrm{g} \cdot \mathrm{kg}_{\mathrm{BW}}^{-1} \cdot \mathrm{d}^{-1}, 3.52 \mathrm{E}-03 \mu \mathrm{g} \cdot \mathrm{kg}_{\mathrm{BW}}^{-1} \cdot \mathrm{d}^{-1}$ and $5.25 \mathrm{E}-04 \mu \mathrm{g} \cdot \mathrm{kg}_{\mathrm{BW}}^{-1} \cdot \mathrm{d}^{-1}$ for ingestion, inhalation and dermal, respectively.

For $\mathrm{Mn}$ in samples the estimated daily intake dose ranges are $(2.8 \mathrm{E}-03$ 7.7E-08 $\left.\mu \mathrm{g} \cdot \mathrm{kg}_{\mathrm{BW}}^{-1} \cdot \mathrm{d}^{-1}\right)$ and $\left(3.0 \mathrm{E}-04-4.4 \mathrm{E}-08 \mu \mathrm{g} \cdot \mathrm{kg}_{\mathrm{BW}}^{-1} \cdot \mathrm{d}^{-1}\right)$ for children and adults, respectively for all three pathways (Table 5). The daily intake doses predicted for both children and adults in Ebedei are below the known reference doses of $4.6 \mathrm{E}-03 \mu \mathrm{g} \cdot \mathrm{kg}_{\mathrm{BW}}^{-1} \cdot \mathrm{d}^{-1}, 1.43 \mathrm{E}-05 \mu \mathrm{g} \cdot \mathrm{kg}_{\mathrm{BW}}^{-1} \cdot \mathrm{d}^{-1}$ and $1.84 \mathrm{E}-03$ $\mu \mathrm{g} \cdot \mathrm{kg}_{\mathrm{BW}}^{-1} \cdot \mathrm{d}^{-1}$ for ingestion, inhalation and dermal, respectively. For Ni in samples the estimated daily intake dose ranges are $\left(1.3 \mathrm{E}-04-3.7 \mathrm{E}-09 \mu \mathrm{g} \cdot \mathrm{kg}_{\mathrm{BW}}^{-1} \cdot \mathrm{d}^{-1}\right)$ 
Table 5. Health risk assessment from exposures to heavy metals.

\begin{tabular}{|c|c|c|c|c|c|c|c|c|c|c|c|c|c|}
\hline \multirow{3}{*}{ Element } & \multirow{3}{*}{$\mathrm{RfD}_{\text {ing }}$} & \multirow{3}{*}{$\mathrm{RfD}_{\text {inh }}$} & \multirow{3}{*}{$\mathrm{RfD}_{\text {derm }}$} & \multirow{3}{*}{ Inh SF } & \multicolumn{3}{|c|}{ DI } & \multicolumn{2}{|c|}{ HQ } & \multicolumn{2}{|c|}{ HI } & \multirow{3}{*}{ LADD } & \multirow{3}{*}{ CR } \\
\hline & & & & & \multicolumn{3}{|c|}{$\left(\mu \mathrm{g} \cdot \mathrm{kg}_{\mathrm{BW}}^{-1} \cdot \mathrm{d}^{-1}\right)$} & \multirow[b]{2}{*}{ Children } & \multirow[b]{2}{*}{ Adult } & \multirow[b]{2}{*}{ Children } & \multirow[b]{2}{*}{ Adult } & & \\
\hline & & & & & & Children & Adult & & & & & & \\
\hline \multirow{3}{*}{$\mathrm{Cd}_{\text {non-cancer }}$} & & & & & Ingestion & $3.2 \mathrm{E}-05$ & $3.4 \mathrm{E}-06$ & $3.2 \mathrm{E}-02$ & $3.4 \mathrm{E}-03$ & \multirow{3}{*}{0.034} & \multirow{3}{*}{0.004} & & \\
\hline & $1.0 \mathrm{E}-03$ & $1.0 \mathrm{E}-03$ & $5.0 \mathrm{E}-05$ & & Inhalation & $8.8 \mathrm{E}-10$ & $5.0 \mathrm{E}-10$ & $8.8 \mathrm{E}-07$ & $5.0 \mathrm{E}-07$ & & & & \\
\hline & & & & & Dermal & $8.8 \mathrm{E}-08$ & $1.3 \mathrm{E}-08$ & $1.8 \mathrm{E}-03$ & $2.6 \mathrm{E}-04$ & & & & \\
\hline \multirow[t]{2}{*}{$\mathrm{Cd}_{\text {cancer }}$} & & & & 6.2 & & & & & & & & $2.5 \mathrm{E}-10$ & $1.6 \mathrm{E}-09$ \\
\hline & & & & & Ingestion & $6.4 \mathrm{E}-04$ & $6.9 \mathrm{E}-05$ & $1.8 \mathrm{E}-01$ & $1.9 \mathrm{E}-02$ & & & & \\
\hline \multirow[t]{3}{*}{$\mathrm{Pb}$} & $3.5 \mathrm{E}-03$ & $3.52 \mathrm{E}-03$ & $5.25 \mathrm{E}-04$ & & Inhalation & $1.8 \mathrm{E}-08$ & $1.0 \mathrm{E}-08$ & $5.1 \mathrm{E}-06$ & $3.0 \mathrm{E}-06$ & 0.184 & 0.020 & & \\
\hline & & & & & Dermal & $1.8 \mathrm{E}-06$ & $2.7 \mathrm{E}-07$ & $3.5 \mathrm{E}-03$ & $5.1 \mathrm{E}-04$ & & & & \\
\hline & & & & & Ingestion & $2.8 \mathrm{E}-03$ & $3.0 \mathrm{E}-04$ & $6.1 \mathrm{E}-02$ & $6.5 \mathrm{E}-03$ & & & & \\
\hline \multirow[t]{3}{*}{$\mathrm{Mn}$} & $4.6 \mathrm{E}-02$ & $1.43 \mathrm{E}-05$ & $1.84 \mathrm{E}-03$ & & Inhalation & $7.7 \mathrm{E}-08$ & $4.4 \mathrm{E}-08$ & $5.4 \mathrm{E}-03$ & $3.1 \mathrm{E}-03$ & 0.071 & 0.010 & & \\
\hline & & & & & Dermal & $7.7 \mathrm{E}-06$ & $1.2 \mathrm{E}-06$ & $4.2 \mathrm{E}-03$ & $6.5 \mathrm{E}-04$ & & & & \\
\hline & & & & & Ingestion & $1.3 \mathrm{E}-04$ & $1.4 \mathrm{E}-05$ & $6.5 \mathrm{E}-03$ & $7.0 \mathrm{E}-04$ & & & & \\
\hline \multirow[t]{2}{*}{$\mathrm{Ni}_{\text {non-cancer }}$} & $2.0 \mathrm{E}-02$ & $2.06 \mathrm{E}-02$ & $5.4 \mathrm{E}-03$ & & Inhalation & $3.7 \mathrm{E}-09$ & $2.1 \mathrm{E}-09$ & $1.8 \mathrm{E}-07$ & $1.0 \mathrm{E}-07$ & 0.007 & 0.001 & & \\
\hline & & & & & Dermal & $3.8 \mathrm{E}-07$ & $5.7 \mathrm{E}-08$ & $7.0 \mathrm{E}-05$ & $1.1 \mathrm{E}-05$ & & & & \\
\hline $\mathrm{Ni}_{\text {cancer }}$ & & & & 0.84 & & & & & & & & $1.0 \mathrm{E}-09$ & $8.9 \mathrm{E}-11$ \\
\hline
\end{tabular}

and $\left(1.4 \mathrm{E}-05-2.1 \mathrm{E}-109 \mu \mathrm{g} \cdot \mathrm{kg}_{\mathrm{BW}}^{-1} \cdot \mathrm{d}^{-1}\right)$ for children and adults, respectively for all three pathways (Table 5). The daily intake doses predicted for both children and adults in Ebedei are below the known reference doses of $2.0 \mathrm{E}-02$ $\mu \mathrm{g} \cdot \mathrm{kg}_{\mathrm{BW}}^{-1} \cdot \mathrm{d}^{-1}, 2.06 \mathrm{E}-02 \mu \mathrm{g} \cdot \mathrm{kg}_{\mathrm{BW}}^{-1} \cdot \mathrm{d}^{-1}$ and $5.4 \mathrm{E}-04 \mu \mathrm{g} \cdot \mathrm{kg}_{\mathrm{BW}}^{-1} \cdot \mathrm{d}^{-1}$ for ingestion, inhalation and dermal, respectively.

Therefore exposures to the individual metals pose no significant risk of non-carcinogenic effects based on the fact that the HI values for the individual metals fell below the threshold value of 1 . The higher $\mathrm{HI}$ values recorded for the children population in this study suggest that children are more at risk of non-carcinogenic at Ebedei following exposure to the dust in their environment. $\mathrm{Pb}$ indicated greater percentage of the minimal risk of non-carcinogenic effects that may be observed among the children and the adult populations, followed, by $\mathrm{Mn}$ and $\mathrm{Cd}$, and $\mathrm{Ni}$.

The assessments of the risk of carcinogenic effects were conducted for $\mathrm{Cd}$ and $\mathrm{Ni}$, and the assessment was done for exposures through the inhalation pathway alone. The cancer risk estimated for $\mathrm{Cd}$ and $\mathrm{Ni}$ were $1.6 \times 10^{-9}$ and $8.9 \times 10^{-11}$, respectively. The cumulatively risk factor, $\left(1.7 \times 10^{-9}\right)$, the estimated cancer risk values in this study are below regulatory range of $10^{-6}-10^{-4}$. Hence, there is a very low tendency for individuals to be at risk of any carcinogenic effect.

\section{Conclusion}


In this study, concentration ranges of $1.2-14.9 \mathrm{mg} / \mathrm{kg}, 44.0-161.6 \mathrm{mg} / \mathrm{kg}$ and $221.3-752.0 \mathrm{mg} / \mathrm{kg}$, and below detection to $29.8 \mathrm{mg} / \mathrm{kg}$ were recorded for $\mathrm{Cd}$, $\mathrm{Pb}, \mathrm{Mn}$ and $\mathrm{Ni}$, respectively. Resultantly, C/PI values of $6,1.1,0.5$ and 0.6 were recorded for $\mathrm{Cd}, \mathrm{Pb}, \mathrm{Mn}$ and $\mathrm{Ni}$, respectively. The cumulative $\mathrm{HI}$ values indicated potential carcinogenic risks for both the children and adult populations were 0.296 and 0.035 , respectively while an estimate of the possible total cancer risk for an individual living within Ebedei Waterside throughout a lifetime gave a cancer risk value of $1.7 \times 10^{-9}$. Although carcinogenic and non-carcinogenic risks for this study were below threshold values, there is an indication that human population from Ebedei may be exposed to elevated doses of potentially toxic metals in indoor environments.

\section{Conflicts of Interest}

The authors declare no conflicts of interest regarding the publication of this paper.

\section{References}

[1] Darus, F.M., Nasir, R.A., Sumari, S.M., Ismail, Z.S. and Omar, N.A. (2012) Heavy Metals Composition of Indoor Dust in Nursery Schools Building. Procedia-Social and Behavioral Sciences, 38, 169-175.

[2] IUPAC (1990) Glossary of Atmospheric Chemistry Terms. International Union of Pure and Applied Chemistry Division, Commission on Atmospheric Chemistry. Pure and Applied Chemistry.

[3] Walker, T.R. (2005) Comparison of Anthropogenic Metal Deposition Rates with Excess Soil Loading from Coal, Oil and Gas Industries in the Usa River Basin, NW Russia. Polish Polar Research, 26, 299-314.

[4] Aucott, M. and Caldarelli, A. (2012) Quantity of Lead Released to the Environment in New Jersey in the Form of Motor Vehicle Wheel Weights. Water, Air, \& Soil Poll, 223, 1743-1752. https://doi.org/10.1007/s11270-011-0979-2

[5] Rasmussen, P.E., Levesque, C., Chénier, M. and Gardner, H.D. (2018) Contribution of Metals in Resuspended Dust to Indoor and Personal Inhalation Exposures: Relationships between PM10 and Settled Dust. Building and Environment, 143, 513-522.

[6] Klepeis, N.E., Nelson, W.C., Ott, W.R., Robinson, J.P., Tsang, A.M., Switzer, P., Behar, J.V., Hern, S.C. and Engelmann, W.H. (2001) The National Human Activity Pattern Survey (NHAPS): A Resource for Assessing Exposure to Environmental Pollutants. Journal of Exposure Science and Environmental Epidemiology, 11, 231-252. https://doi.org/10.1038/sj.jea.7500165

[7] Nor, A.A.W., Fairus, M.D., Norain, I., Siti, M.S. and Nur, F.M.H. (2012) Heavy Metals Concentrations of Settled Surface Dust in Residential Building. The Malaysian Journal of Analytical Sciences, 16, 18-23.

[8] Al-Rahji, M.A. and Seaward, M.R.D. (1996) Metal Levels in Indoor and Outdoor Dust in Riyadh, Saudi Arabia. Environment International, 22, 315-324. https://doi.org/10.1016/0160-4120(96)00017-7

[9] Thatcher, T.L. and Layton, D.W. (1995) Deposition, Resuspension, and Penetration of Particles within a Residence. Atmospheric Environment, 29, 1487-1497. 
[10] Kurt-Karakus, P.B. (2012) Determination of Heavy Metals in Indoor Dust from Istanbul, Turkey: Estimation of the Health Risk. Environment International, 50, 47-55. https://doi.org/10.1016/j.envint.2012.09.011

[11] Mielke, H.W., Gonzales, C.R., Smith, M.K. and Mielke, P.W. (1999) The Urban Environment and Children's Health: Soils as an Integrator of Lead, Zinc, and Cadmium in New Orleans, Louisiana, U.S.A. Environmental Research, 81, 117-129. https://doi.org/10.1006/enrs.1999.3966

[12] Liu, Y.Z., Ma, J.W., Yan, H.X., Ren, Y.Q., Wang, B.B., Lin, C.Y. and Liu, X.T. (2016) Bioaccessibility and Health Risk Assessment of Arsenic in Soil and Indoor Dust in Rural and Urban Areas of Hubei Province, China. Ecotoxicology and Environment Safety, 126, 14-22. https://doi.org/10.1016/j.ecoenv.2015.11.037

[13] Adekola, F.A. and Dosumu, O.O. (2001) Heavy Metal Determination in Household Dusts from Ilorin City, Nigeria. Nigerian Society for Experimental Biology, 1, 217-222.

[14] Molhave, L., Schneider, T., Kjaergaard, S.K., Larsen, L., Norn, S. and Jorgensen, O. (2000) House Dust in Seven Danish Offices. Atmospheric Environment, 34 4767-4779.

[15] Sharpe, M. (2004) Safe as Houses? Indoor Air Pollution and Health. Journal of Environmental Monitoring. JEM, 6, 46N-49N.

[16] Mitchel, C.S., Zhang, J.J., Sigsgaard, T., Jantunen, M., Lioy, P.I., Samson, R. and Karol, M.H. (2007) Current State of the Science: Health Effects and Indoor Environmental Quality. Environmental Health Perspectives, 115, 958. https://doi.org/10.1289/ehp.8987

[17] Wu, F., Jacobs, D., Mitchell, C.S., Miller, D. and Karol, M.H. (2007) Improving Indoor Environmental Quality for Public Health: Impediments and Policy Recommendations. Environmental Health Perspectives, 115, 953. https://doi.org/10.1289/ehp.8986

[18] Byrne, M. (1998) Aerosols Exposed. Chemistry in Britain, 34, 23-26.

[19] Fillol, C., Dor, F., Denys, S., Tack, K., Labat, L. and Seta, N. (2013) Arsenic Urinary Concentrations in Children Living in a Naturally Arsenic Contaminated Area. Journal of Exposure Science \& Environmental Epidemiology, 23, 145-150. https://doi.org/10.1038/jes.2012.72

[20] Acosta, J.A., Cano, A.F., Arocena, J.M., Debela, F. and Martinez, S. (2009) Distribution of Metals in Soil Particle Size Fractions and Its Implication to Risk Assessment of Playgrounds in Murcia City (Spain). Geoderma, 149, 101-109. https://doi.org/10.1016/j.geoderma.2008.11.034

[21] Anejionu, O.C., Whyatt, J.D., Blackburn, G.A. and Price, C.S. (2015) Contributions of Gas Flaring to a Global Air Pollution Hotspot: Spatial and Temporal Variations, Impacts and Alleviation. Atmospheric Environment, 118, 184-193. https://doi.org/10.1016/j.atmosenv.2015.08.006

[22] Zakrzewski, S.F. (2002) Environmental Toxicology. 3rd Edition, Oxford University Press, New York.

[23] Soltanieh, M., Zohrabian, A., Gholipour, M.J. and Kalnay, E. (2016) A Review of Global Gas Flaring and Venting and Impact on the Environment: Case Study of Iran. International Journal of Greenhouse Gas Control, 49, 488-509. https://doi.org/10.1016/j.ijggc.2016.02.010

[24] Iwegbue, C.M.A., Nwajei, G.E., Ogala, J.E. and Overah, C.L. (2010) Determination of Trace Metal Concentrations in Soil Profiles of Municipal Waste Dumps in Nigeria. Environmental Geochemistry and Health, 32, 415-430. 
https://doi.org/10.1007/s10653-010-9285-y

[25] Heinike, H.J., Eckrelman, W., Thomasson, A.J., Jones, R.J.A., Montanarella, L. and Buckley, B. (2000) European Soil Bureau. Research Report No. 4, Office for Official Publication of the European Communities, 393.

[26] DPR (2000) Environmental Guidelines and Standard for the Petroleum Industry in Nigeria. Revised Edition, Department of Petroleum Resources, Ministry of Petroleum and Mineral Resources, Abuja.

[27] US EPA (1996) EPA/540/r-95/128. Office of Soil Waste and Emergency Response, Washington DC.

[28] Ferreira-Baptista, L. and De Miguel, E. (2005) Geochemistry and Risk Assessment of Street Dust in Luanda, Angola: A Tropical Urban Environment. Atmospheric Environment, 39, 4501-4512. https://doi.org/10.1016/j.atmosenv.2005.03.026

[29] Van den Berg, R. (1995) RIVM Report No. 725201011. National Institute of Public Health and Environmental Protection (RIVM), Bilthoven.

[30] US EPA (2011) Regional Screening Level Table for Chemical Contaminants Ate Superfund Sites. US Environmental Protection Agency, Washington DC.

[31] US EPA (2001) EPA/600/P-95/002Fa-c. US EPA National Centre for Environment, Office of Research and Development, Washington DC.

[32] US EPA (1989) EPA/se0/1-89/002. Office of Solid Waste and Emergency Response, Washington DC.

[33] Ize-Iyamu, O.K. and Bernard, A.E. (2007) The Effects of Petroleum Exploration and Production Operations on the Heavy Metals Contents of Soil and Groundwater in the Niger Delta. International Journal of Physical Sciences, 2, 271-275.

[34] Li, Y.W., Pi, L., Hu, W.L., Chen, M.Q., Luo, Y., Li, Z., Su, S.J., Gan, Z.W. and Ding, S.L. (2016) Concentrations and Health Risk Assessment of Metal(Loid)s in Indoor Dust from Two Typical Cities of China. Environmental Science and Pollution Research, 23, 9082-9092.

[35] Lin, Y.S., Fang, F.M., Wang, F. and Xu, M.L. (2015) Pollution Distribution and Health Risk Assessment of Heavy Metals in Indoor Dust in Anhui Rural, China. Environmental Monitoring and Assessment, 187, 565. https://doi.org/10.1007/s10661-015-4763-4

[36] Olujimi, O., Steiner, O. and Goessler, W. (2015) Pollution Indexing and Health Risk Assessments of Trace Elements in Indoor Dusts from Classrooms, Living Rooms and Offices in Ogun State, Nigeria. Journal of African Earth Science, 101, 396-404. https://doi.org/10.1016/j.jafrearsci.2014.10.007 


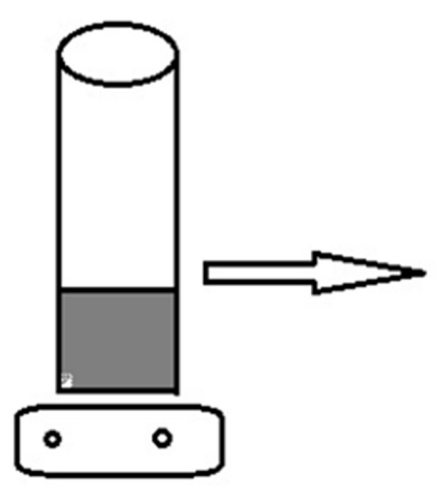

Digestion of dust Aqua regia

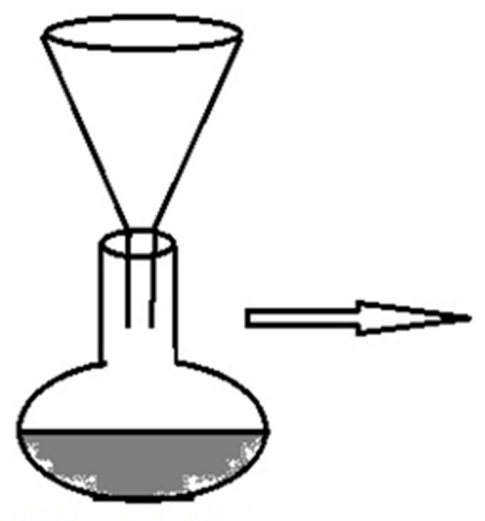

Filtration of digest

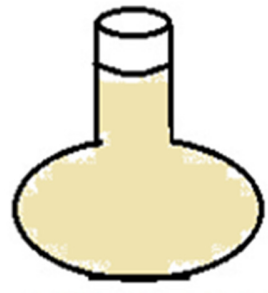

Add water to mark

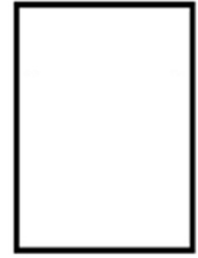

Analysis of digest with ICPMS

Flowchart of experimental procedure. 